UDC $621.391(045)$,

DOI: $10.18372 / 1990-5548.52 .11863$

${ }^{1}$ V. M. Sineglazov,

${ }^{2}$ E. V. Daskal

\title{
IEEE 802.15.4 / ZIGBEE WIRELESS NETWORK AS A BASIS FOR UAV NAVIGATION SYSTEM
}

${ }^{1,2}$ Educational \& Research Institute of Information and Diagnostic Systems, National Aviation University, Kyiv, Ukraine

E-mails: 1'svm@nau.edu.ua, 22evg.daskal@gmail.com

\begin{abstract}
Modern unmanned aerial vehicle navigation systems are highly dependent on Global Positioning System signals. Since Global Positioning System signals in dense urban housing areas, in tunnels or indoors may be unreliable, unmanned aerial vehicle will not be able to fulfill its tasks if needed to pass such zones. An unmanned aerial vehicle navigation system based on on the increasingly popular radio standard IEEE 802.15.4 / ZigBee is proposed. A description of such networks and their advantages for unmanned aerial vehicle positioning are given.
\end{abstract}

Index Terms-Unmanned aerial vehicle; Global Positioning System; mesh-network; ZigBee; IEEE 802.15.4; wireless personal area network.

\section{INTRODUCTION}

Wireless data transmission using short-range devices is becoming more and more widely used in automated control systems. One of the wireless network types gaining popularity are wireless personal area network (WPAN), or wireless sensor networks. WPAN is used to connect various devices, including computers, home and office equipment, communication devices, sensors, etc. WPAN is used both to connect individual devices to each other, and to connect them to the networks of a higher level, for example, the global Internet network.

The wireless network technology of sensor networks today is, perhaps, a wireless technology that can work for a long time autonomously, without recharging or replacing batteries. WPAN coverage ranges from several centimeters to tens of meters, and can be extended to a quite large coverage area due to the ability of each network node node to retranslate the message.

Wireless personal area network may be deployed using different networking technologies, such as Bluethooth (IEEE 802.15.1), Wi-Fi (IEEE 802.11), and ZigBee (IEEE 802.15.4). When deployin communication network using ZigBee it becomes possible to create a distributed self organizing system for the collection, processing and transmition of information.

Wireless global positioning systems such as Global Positioning System (GPS) allow to determine the position of objects (including moving objects) in time and space and to provide reliable estimates of their coordinates in virtually any location on earth. At the same time, such systems have a significant drawback - most often, they do not work or work poorly indoors or urban areas where dense and tall housing may impair communication with the satellites, which limits the use of the unmanned aerial vehicle (UAV). Local positioning system based on WPAN networks are designed to eliminate this drawback.

To solve the problem of local positioning and provide accurate coordinate information, it is possible to use wireless sensor networks, in particular the IEEE 802.15.4/ZigBee wireless network.

\section{PROBLEM StATEMENT}

Most of UAVs to date can not independently carry out complex tasks, being in essence the remote-controlled aircrafts that are critically dependent on commands from the ground, and navigation system signals. UAV navigation system basis is made of global satellite navigation systems receiver and spatial orientation inertial sensor units used in conjunction with such systems [1].

Satellite navigation systems (e.g. GPS or GLONASS) allow to obtain accurate information about the current location in any weather conditions, anywhere in the earth's surface, provided the receiver being in line of sight of at least 3 satellites.

Disadvantages of the GPS system are periodic failures in the operation of receiving devices due to unstable signal from satellites. A stable signal requires communication with at least ten satellites, although it is sufficient to obtain data from three satellites to determine the location. In addition significant errors in determining the current location of the object are possible when using GPS navigation, especially when driving at high speed. Therefore, in the conditions of dense construction or when it is necessary to fly indoors or through a tunnel, the use of such systems in the UAV causes difficulties. 
Inertial navigation systems (INS) are built on the basis of gyroscopes and accelerometers. They continuously provide information about the course, coordinates, speed and parameters of the angular orientation of the UAV. Inertial systems have major and important advantages compared to other navigation systems: universal application, ability to determine the basic parameters of motion, autonomous action, absolute noise immunity.

However, INS are complex and expensive, they require careful care and may have quite a lot of weight which makes their use in UAVs problematic. The accuracy of uncorrected inertial navigation system depends on time due to increasing error as a consequence of the gyroscopic drift. Therefore, obtaining information that meets specified requirements from the uncorrected INS is limited in time. The best samples are capable of maintaining accuracy within no more than 10 minutes of no signal from satellites. As a rule, in this case it is required to maintain the regime of rectilinear motion without accelerations.

Various methods of correction are applied to reduce errors and expand the possibilities of use, including satellite navigation data usage. This increases the accuracy of navigation system, but leads to a loss of their autonomy and noise immunity.

The continuous development of wireless technologies and the growing popularity of embedded radio transceivers allow us to talk about the imminent increase in the availability of such devices on the market, namely, reducing their cost and simplifying their use. Therefore, it makes sense to consider their application for building the navigation system of a UAV.

\section{WIRELESS SENSOR MESH-NETS}

One of the most notable trends in the development of the modern world and technology is the concept of "the Internet of things" (IoT), which involve connection of "smart" electronic devices in the network and further connection to the Internet for information sharing and remote management. This concept is associated with the development of wireless sensor network technology [2].

Wireless sensor network - a distributed, self-organizing network of many sensors and actuators connected to each other via radiochannel. The coverage area of such network can range from several meters to several kilometers due to the ability to transmit messages from one element to another. This technology is used to solve many practical problems related to monitoring, management, logistics, etc.
Since the wireless sensor network includes an array of nodes arranged in a certain area such networks use mesh topology and can be used as a basis for the UAV navigation system. The mesh topology network or a mesh-net is a distributed wireless network that the device can combine three types: 1) coordinators; 2) routers; 3) final devices (Fig. 1).

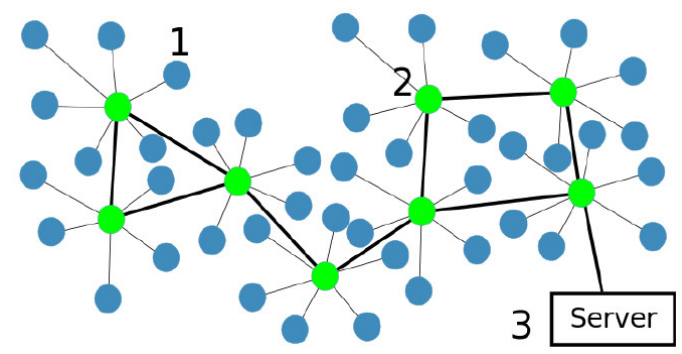

Fig. 1. Topology of a mesh-net

The coordinator or the server is the main device in the network which provides networking, chooses the security policy, enables or disables network connection to new nodes, as well as collects and processes information from all devices and sends the results to an external network (e.g. Internet).

Routers are responsible for redirecting packets to the network. Nodes of this type are responsible for routing the network traffic. They are also involved in the search for a new route to deliver a message, if any of the intermediate devices on the old route are out of order.

The end devices are the executive devices on the network, they receive and send messages to the server and perform the necessary actions. Such devices most of the time can be in a sleep mode and perform the reception-transmission of messages to the nearest router only if necessary (pressing a button, timer or sensor triggering). Thanks to this the end devices can work long enough from the built-in power supply.

It is worth noting that the devices distribution for these types is conditional and is entirely software. Hardware-wise all devices may be identical. Coordinators and routers can also perform the functions of target devices.

Proceeding from this, it is possible to highlight the main advantages of the mesh network topology in comparison with the classical topology of the "star" type:

- noise immunity due to retransmission of messages in the event of an error and the use of alternative routes;

- low power consumption due to less powerful transmitters. It is enough for each node of the network to communicate with at least one neighboring router; 
- self-organization and self-repair of the network in case of failures. The rules for connecting devices and encrypting messages are determined by the standard and the software used.

Thus, if you know the location coordinates in the sensor network and the devices mounted on the UAV transceiver that will also be part of the network can then determining the location of the UAV by measuring the distance to the nearest stationary nodes becomes possible. Moreover, a two-way message exchange is possible: between a ground station and a UAV, and between several UAVs in the air. Each node in the network can know the coordinates of all other nodes and, depending on this, give certain commands or perform certain actions.

\section{IEEE 802.15.4 STANDARD}

To date, a number of wireless standards as well as the corresponding element base are developed and available for use to create positioning systems.

Although wireless mesh-net can be constructed based on any standard wireless networks, whether it be Bluethooth (IEEE 802.15.1), or Wi-Fi (IEEE 802.11), the most applicable will be using IEEE 802.15 .4 standard.

IEEE 802.15.4 standard defines the lower layer (PHY and MAC levels of the OSI model) for wireless personal area networks (WPAN). Such networks are focused on the low equipment cost and low communication speed between devices (up to $250 \mathrm{Kbps})$. The emphasis is on the very low cost of communication with the nearest devices, completely without (or with a small) basic structure, in order to be used at an unprecedented low level of energy. The main distinguishing feature of the standard compared to other wireless personal networks is the low cost of production and operating costs and the simplicity of the technology. Compatible with 802.15.4 standard devices can use one of three possibile unlicensed frequency bands: 868.0-868.6 MHz, 902-928 MHz, 2400-2483.5 MHz.

Despite the fact that the standard assumes a relatively low transfer rate (up to $250 \mathrm{Kbps}$ ), its quite enough for sending and receiving commands and UAV coordinates. The range of the transmitters of this standard depends on the use of the amplifier and is within the 50-1000 $\mathrm{m}$ range. Utilizing mesh-net the coverage area of the network can be increased depending on the number of devices.

The most popular protocol stack is by far the ZigBee, based on which complicated, safe and resistant mesh-nets can be built. Ample selection of transceivers, SoCs (System-on-Chip) and complete radiounits designed for use in a ZigBee network is available on the market. It is worth noting ZigBit complete radiounits produced by Atmel company (which was recently acquired by Microchip).

Complete radiounits or separate transceivers compliant with IEEE 802.15.4 standard significantly simplificaties the program design since all the work at the lower levels (MAC and PHY) has been already implemented in the hardware or firmware of the transceiver level, and the upper levels of the work provided by selected protocols stack, e.g. ZigBee.

\section{UAV POSITIONING IN THE WIRELESS NETWORK}

Thus, by unfolding IEEE 802.15.4 / ZigBee network in a particular area where the use of UAVs is expected, it is possible to use the nodes of this network as a reference because of known coordinates. The density of network nodes placement depends on their radio transmitter power and the number of nodes determines the coverage of the territory. Due to IEEE 802.15.4 standard focus on low power consumption and ease of use, the network nodes can have small dimensions and be powered long enough by a built-in battery and solar panel. This allows node placement in remote locations or making them unnoticeable. At the same time, because ZigBee type technology enables wireless control of home, office and industrial buildings, it is assumed that in the near future in many buildings and structures will have ZigBee network deployed as a part of the building infrastructure itself. Moreover there is the concept of "smart cities", which involves the integration of all infrastructure and industrial urban sites into a single network, where an important role is given to the use of UAV [3]. All these ZigBee-compatible devices can be used to build the navigation system. The additional amount of code required to use a network node as a reference does not exceed one kilobyte.

To determine the location of the radio on the plane, there are two basic ways. The first way is to locate distances up to three points, whose location is known. The second method - determining the coordinates of two angles formed by the line connecting the two points whose coordinates are known, and the lines passing through these points and the desired point [4]. The distance between the radio receiver and radio transmitter can be measured in several ways, one of them - the distance measurement by the received signal power level (RSSI).

Flying between network nodes UAV may determine its position based on the signal power (Received signal strength indicator, RSSI) received from the closest radio transmitters the coordinates of which are known (Fig. 2). Unfortunately, the signal strength can vary greatly influenced by external random factors. To reduce the influence of random 
factors, the computer uses data from several (3 to 16) nearest transmitters. If the number is more than 16 , then the 16 most powerful signals are used. In general, this leads to an averaging of the calculation results

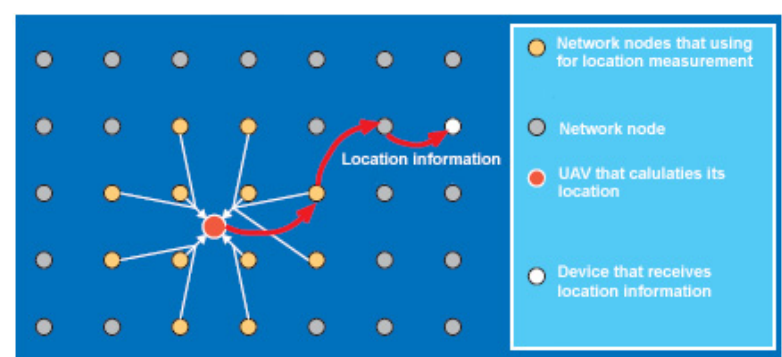

Fig. 2. ZigBee network with messaging and positioning capabilities

Coverage can be increased in two ways :

1) By increasing reference nodes transmitters power while reducing the accuracy and resolution of the position calculation.

2) By distribute the reference nodes over a large area and carrying out the calculation of the position with respect to the nodes with the highest signal levels.

The second approach seems preferable since it allows to increase the coverage area without decreasing accuracy. It's implemented as follows: UAV sends a broadcast packet and collects data from all of the neighboring nodes in the radio visibility zone. From the responses received the highest power signals are chosen and coordinates of the corresponding reference unit are taken as initial or zero coordinates for the calculation. Next, based on the new initial coordinates, all of the nearest reference nodes coordinates are converted. The results are the UAV coordinates with respect to a reference node with the highest signal power. To get the true coordinates in a large network, it is necessary to add to the obtained values reference node's own position coordinates.

\section{CONCLUSION}

The gaining popularity IEEE 802.15.4 / the ZigBee standard allows to deploy a wireless sensor network, which has the potential to cover a large area up to the whole city, relatively fast, easy, and inexpensive. IEEE 802.15.4 / ZigBee Standard provides the function of indicating the received signal strength RSSI that can be used to determine the location of the UAV flying through a network, and which in turn is part of that network. At the same time, as a bonus, it is possible to communicate with UAV anywhere on the network. This offers great opportunities to control multiple UAVs from anywhere in the world (provided sensor network has a connection to the Internet) and provides reliable navigation UAV to complete a task in a dense housing, in tunnels or indoors. Thanks to the low-cost and easy to use radiounits the IEEE 802.15.4 / the ZigBee standard has reduced development time, cost and weight.

\section{REFERENCES}

[1] A. A. Loskutnikov, N. S. Senjushkin, and V. V. Paramonov, "UAV automatic control systems," Young Scientist, no. 9, pp. 56-58, 2011. (in Russian)

[2] I. E. Osipov, "Mesh-networks: technologies, applications, equipment," Technologies and means of communication, no. 4, pp. 39-45, 2006. (in Russian)

[3] A. Vyrelkin, and A. Koucheryavy, "Using of Unmanned Aerial Vehicles for Solving the Problems of the Smart City," Telecom IT, vol. 5, Iss. 1, pp. 105-113, 2017. (in Russian).

[4] A. A. Bodrova, and V. I. Logvin, "Positioning and interaction in wireless sensor networks" Young Scientist, no. 6, pp. 129-132, 2015.

Received February 21, 2017

Sineglazov Viktor. Doctor of Engineering Science. Professor.

Educational \& Research Institute of Information and Diagnostic Systems, Aviation Computer-Integrated Complexes Department, National Aviation University, Kyiv, Ukraine.

Education: Kiev Polytechnic Institute. Kiev, Ukraine (1973).

Research interests: Air Navigation, Air Traffic Control, Identification of Complex Systems, Wind/solar power plant, Neural Network.

Publications: more than 600 papers.

E-mail:svm@nau.edu.ua

Daskal Evgen. Post-graduate student.

Aviation Computer-Integrated Complexes Department, Educational \& Research Institute of Information and Diagnostic Systems, National Aviation University, Kyiv, Ukraine.

Education: National Aviation University, Kyiv, Ukraine (2014).

Research area: programming, microprocessors, systems and process control, computer-aided design, unmanned aerial vehicles.

Publications: 3 .

E-mail: evg.daskal@gmail.com 


\section{В. М. Синсглазов, С. В. Даскал. Бездротова мережа стандарту IEEE 802.15.4 / ZigBeе, як основа навігаційної системи БПЛА}

Сучасні навігаційні системи безпілотних літальних апаратів сильно залежать від наявності сигналів глобальної супутникової системи позиціонування. Оскільки супутникові сигнали в умовах щільної забудови або в тунелях чи приміщеннях можуть бути нестійкими, безпілотний літальний апарат не зможе виконувати свої задачі при необхідності прольоту повз такі зони. Запропоновано використовувати навігаційну систему для безпілотних літальних апаратів на основі радіомереж стандарту IEEE 802.15.4 / ZigBee, що набирає популярність. Наведено опис таких мереж і переваг їх використання для позиціонування безпілотних літальних апаратів.

Ключові слова: безпілотний літальний апарат; супутникова система навігації; mesh-мережа; ZigBee; IEEE 802.15.4; бездротова персональна мережа.

Синсглазов Віктор Михайлович. Доктор технічних наук. Професор.

Кафедра авіаційних комп'ютерно-інтегрованих комплексів, Навчально-науковий інститут інформаційно-діагностичних систем, Національний авіаційний університет, Київ, Україна.

Освіта: Київський політехнічний інститут. Київ, Україна (1973).

Напрям наукової діяльності: аеронавігація, управління повітряним рухом, ідентифікація складних систем, вітроенергетичні установки.

Кількість публікацій: більше 600 наукових робіт.

E-mail: svm@nau.edu.ua

Даскал Свген Вікторович. Аспірант.

Кафедра авіаційних комп’ютерно-інтегрованих комплексів, Національний авіаційний університет, Київ, Україна. Освіта: Національний авіаційний університет, Київ, Україна (2014).

Напрям наукової діяльності: програмування, мікроконтролери, системи та процеси керування, системи автоматизованого проектування, безпілотні літальні апарати.

Кількість публікацій: 3.

E-mail: evg.daskal@gmail.com

В. М. Синеглазов, Е. В. Даскал. Беспроводная сеть стандарта IEEE 802.15.4 / ZigBee, как основа навигационной системы БПЛА

Современные навигационные системы беспилотных летательных аппаратов сильно зависят от наличия сигналов от глобальной спутниковой системы позиционирования. Поскольку спутниковые сигналы в условиях плотной застройки либо в тоннелях или помещениях могут быть неустойчивыми, беспилотный летательный аппарат не сможет выполнять свои задачи при необходимости пролета через такие зоны. Предложено использовать навигационную систему для беспилотных летательных аппаратов на основе радиосетей набирающего популярность стандарта IEEE 802.15.4 / ZigBee. Приведено описание таких сетей, и преимуществ их использования для позиционирования беспилотных летательных аппаратов.

Ключевые слова: беспилотный летательный аппарат; спутниковая система навигации; mesh-ceть; ZigBee; IEEE 802.15.4; беспроводная персональная сеть.

Синеглазов Виктор Михайлович. Доктор технических наук. Профессор.

Кафедра авиационных компьютерно-интегрированных комплексов, Учебно-научный институт информационно-диагностических систем, Национальный авиационный университет, Киев, Украина.

Образование: Киевский политехнический институт. Киев, Украина (1973).

Направление научной деятельности: аэронавигация, управление воздушным движением, идентификация сложных систем, ветроэнергетические установки.

Количество публикаций: более 600 научных работ.

E-mail: svm@nau.edu.ua

Даскал Евгений Викторович. Аспирант.

Кафедра авиационных компьютерно-интегрированных комплексов, Учебно-научный институт информационно-диагностических систем, Национальный авиационный университет, Киев, Украина.

Образование: Национальный авиационный университет, Киев, Украина (2014).

Направление научной деятельности: программирования, микроконтроллеры, системы и процессы управления, системы автоматизированного проектирования, беспилотные летательные аппараты.

Количество публикаций: 3.

E-mail: evg.daskal@gmail.com 